\title{
YOGURT KACANG MERAH PLUS SUSU KAMBING SEBAGAI SNACK SEHAT TINGGI ZAT BESI BAGI REMAJA ANEMIA
}

\author{
Red Bean Plus Goat Milk Yoghurt as a Healthy Snack with High Iron Content Towards \\ Anemic Teenagers
}

\author{
Afina Rachma Sulistyaning, Widya Ayu Kurnia Putri, Hery Winarsi, Armaida Fitri \\ Program Studi Ilmu Gizi, Fakultas IImu-ilmu Kesehatan, Universitas Jenderal Soedirman \\ E-mail: afina.sulistyaning@unsoed.ac.id
}

\begin{abstract}
The high prevalence of anemic adolescents in Indonesia resulted in urgent demand for a food product with high iron content as a healthy snack. This research aims to produce the best formula for red bean plus goat milk yogurt. The method was a randomized group design with two factors; the proportion of red bean and goat milk (100:0; 90:10; 80:20; 70:30), and fermentation time (12 and 24 hours). The organoleptic test includes flavor, smell, viscosity, color, and preference using a preference test with 55 panelists. Iron contents measured using the AAS method. The data were analyzed using ANOVA followed by Duncan's Multiple Range Test. Organoleptic results analyzed using the Friedman test followed with a double comparative test. The best formula determined based on iron content and organoleptic results using the effectivity index. Red bean and goat milk proportion significantly affect iron content $(p=0.037)$. The combination of fermentation time and red bean-goat milk proportion significantly affects the sensory quality $(p=0.000)$. Fermentation time had no significant effect on iron content $(p=0.83)$. The iron contents were $23.30-33.62 \mathrm{mg} / \mathrm{L}$. The best product has a red bean and goat milk proportion of 90 percent:10 percent, 24 hours fermentation, and $33.62 \mathrm{mg} / \mathrm{ml}$ iron content. The serving size is $80 \mathrm{ml}$, fulfilled 10.35 percent daily iron need of female adolescents.
\end{abstract}

Keywords: anaemic, red bean, healthy snacks, goat milk, yoghurt

\section{ABSTRAK}

Prevalensi anemia pada remaja putri masih tinggi di Indonesia, sehingga dibutuhkan sebuah produk pangan tinggi zat besi $(\mathrm{Fe})$ sebagai snack sehat. Penelitian ini bertujuan untuk mendapatkan formula terbaik dari yogurt kacang merah plus susu kambing sebagai produk kaya zat besi. Penelitian ini menggunakan metode rancangan acak kelompok dua faktor terdiri dari proporsi kacang merah dan susu kambing (100:0; 90:10; 80:20; 70:30), serta lama fermentasi 12 dan 24 jam dengan 3 kali ulangan, sehingga terdapat 24 unit percobaan. Uji organoleptik produk meliputi rasa, aroma, kekentalan, warna, dan kesukaan menggunakan uji kesukaan berskoring 1-5, dengan jumlah panelis sebanyak 55 orang. Kadar Fe produk ditentukan menggunakan metode AAS. Data dianalisis menggunakan ANOVA, dilanjutkan uji Duncan's Multiple Range Test. Data organoleptik diuji Friedman dan dilanjutkan dengan uji banding ganda. Untuk mengetahui formula terbaik berdasarkan kadar Fe dan organoleptik menggunakan indeks efektivitas. Proporsi kacang merah dan susu kambing berpengaruh nyata terhadap kadar $\mathrm{Fe}(p=0.037)$. Kombinasi lama fermentasi dan proporsi kacang merah dan susu kambing juga berpengaruh terhadap kualitas sensori $(p=0.000)$, tetapi lama fermentasi tidak berpengaruh terhadap kadar $\mathrm{Fe}(p=0.83)$. Yogurt terbaik memilki proporsi kacang merah:susu kambing sebesar 90 persen:10 persen, dengan lama fermentasi $24 \mathrm{jam}$ dan kadar Fe $33.62 \mathrm{mg} / \mathrm{ml}$. Serving size yogurt sebesar $80 \mathrm{ml}$ telah memenuhi kebutuhan Fe remaja putri sebanyak 10.35 persen.

Kata kunci: anemia, kacang merah, snack sehat, susu kambing, yogurt 


\section{PENDAHULUAN}

$\mathrm{P}$ emenuhan kebutuhan gizi optimal dan seimbang merupakan faktor penting untuk mencapai kondisi kesehatan yang prima bagi setiap individu. Akan tetapi, prevalensi overweight akibat asupan yang tidak seimbang meningkat beberapa tahun terakhir ${ }^{1-}$ 3 , sedangkan prevalensi underweight masih menjadi masalah di beberapa negara di dunia ${ }^{4}$. Oleh karena itu, individu dengan obesitas maupun underweight menjadi masalah terkait dengan kebutuhan gizi harian ${ }^{5}$. Berbagai studi telah mencoba menjelaskan bahwa kondisi demikian diakibatkan oleh konsumsi makanan jajanan yang berlebih, tetapi rendah kandungan gizi esensial ${ }^{6}$. Efek negatif dari konsumsi jajanan berlebih akan semakin meningkat jika berakibat pada gangguan waktu pola makan. Beberapa penelitian telah menyatakan bahwa pola makan tidak teratur dapat berakibat pada berbagai permasalahan gizi, termasuk obesitas dan underweight ${ }^{7-10}$.

Kebiasaan konsumsi jajanan tidak sehat dapat berdampak buruk pada berbagai permasalahan gizi di segala usia, termasuk remaja ${ }^{10,11}$. Dilaporkan bahwa masa remaja merupakan periode kehidupan yang sangat penting terkait dengan peningkatan kebutuhan gizi yang signifikan untuk memenuhi kebutuhannya selama proses pertumbuhan dan perkembangan ${ }^{12}$. Salah satu permasalahan gizi utama yang serigkali muncul di usia remaja yang berkaitan dengan kondisi obesitas maupun underweight adalah anemia pada remaja putri13,14. Pada tahun 2005 , prevalensi anemia sebesar 24,8 persen populasi dunia dan jumlah ini meningkat menjadi 32,9 persen di tahun 201015,16. Di wilayah Banyumas, dimana penelitian ini dilakukan, sebuah penelitian telah melaporkan adanya 92,9 persen sampel remaja putri usia Sekolah Menengah Atas (SMA) yang mengalami anemia di wilayah perkotaan, sedangkan di wilayah perdesaan sedikit lebih rendah yaitu 75 persen remaja ${ }^{17}$.

Konsumsi makanan jajanan tinggi kalori dan rendah vitamin mineral diyakini merupakan kontributor utama masalah gizi termasuk anemia. Meski demikian, jajanan sehat sulit ditemukan. Karena itu, penting ditemukannya jajanan sehat khususnya untuk remaja anemia. Kacang merah memiliki kandungan serat (4\%), protein $(29.1 \%)$, asam lemak tidak jenuh, dan vitamin $\mathrm{E}^{18}$. Kacang merah juga dikenal sebagai makanan dengan sumber zat besi non-heme. Sumber zat besi non-heme memiliki bioavailabilitas lebih rendah disbanding heme, namun bahan nabati tersebut dapat tersedia sebagai Ferritin dalam bentuk $\mathrm{Fe}^{3+}$ teroksidasi yang dibungkus cangkang peptide yang aman dikonsumsi ${ }^{19}$.

Berdasarkan faktor-faktor yang menguntungkan tadi, kacang merah memiliki potensi yang sangat baik untuk dikembangkan sebagai bahan dasar makanan jajanan sehat. Hanya saja, kacang merah cenderung memiliki rasa yang kurang dapat diterima jika tidak diolah lebih lanjut, sehingga penelitian ini mencoba untuk mengoptimalkan tingkat penerimaan kacang merah dengan mengolahnya menjadi yoghurt. Kacang merah sangat memungkinkan untuk diolah menjadi bentuk yoghurt, karenamengandung karbohidrat sederhana (glukosa dan maltose), protein, vitamin, dan mineralnya merupakan zat gizi yang dibutuhkan untuk pertumbuhan bakteri asam laktat 20,21 .

Untuk mengurangi risiko alergi yang banyak terjadi pada susu sapi, penelitian ini menggunakan susu kambing sebagai sumber laktosa. Menurut penelitian sebelumnya, kandungan lemak dan protein susu sapi lebih mudah untuk dicerna, sedangkan kandungan vitamin B6, B1, dan B3 susu kambing lebih tinggi dari susu sapi22,23. Akan tetapi, susu kambing cenderung memiliki aroma yang kurang menarik dibandingkan dengan susu sapi. Oleh karena itu, untuk mengurangi kondisi yang tidak diharapkan, Lactobacillus bulgaricus dan Streptococcus thermophillus digunakan sebagai starter yogurt yang secara alamiah akan memecah laktosa menjadi asam laktat, sehingga diharapkan dapat mengurangi bau susu kambing menjadi bau khas yogurt 24 . Berdasarkan latar belakang tersebut, penelitian ini bertujuan untuk mendapatkan formula terbaik dari yogurt kacang merah plus susu kambing sebagai produk kaya zat besi. 
Tabel 1

Kombinasi Produk Berdasarkan Lama Fermentasi dan Proporsi Bahan

\begin{tabular}{ccccc}
\hline $\mathrm{T} 1$ & $\mathrm{P} 1$ & $\mathrm{P} 2$ & $\mathrm{P} 3$ & $\mathrm{P} 4$ \\
\hline $\mathrm{T} 2$ & $\mathrm{~T} 1 \mathrm{P} 1$ & $\mathrm{~T} 1 \mathrm{P} 2$ & $\mathrm{~T} 1 \mathrm{P} 3$ & $\mathrm{~T} 1 \mathrm{P} 4$ \\
\hline
\end{tabular}

Keterangan: Kombinasi proporsi kacang merah (\%):susu kambing (\%) = P1 (100:0); P2 (90:10); P3

(80:20); P4 (70:30), waktu fermentasi = T1 (12 hours); T2 (24 hours)

\section{METODE PENELITIAN}

\section{Desain, waktu, dan lokasi penelitian}

Penelitian ini bersifat eksperimental dengan rancangan acak kelompok dua faktor, yaitu: proporsi kacang merah dan susu kambing $(P)$ dan lama fermentasi $(T)$. Detail kombinasi penelitian ini dapat dilihat pada Tabel 1. Penelitian ini dilaksanakan bulan April Agustus 2018 di Laboratorium IImu Teknologi Pangan, Universitas Jenderal Soedirman.

Bahan mentah yang digunakan untuk pengembangan produk pada penelitian ini adalah kacang merah yang tidak dikupas kulitnya dan didapatkan di Pasar Wage, Purwokerto, Jawa Tengah. Susu kambing diperoleh dari Experimental Farm, Fakultas Peternakan, serta bakteri asam laktat sebagai starter produk yogurt juga diperoleh dari Fakultas Peternakan, Universitas Jenderal Soedirman.

\section{Pembuatan Yogurt Kacang Merah Plus Susu Kambing}

Pembuatan yogurt kacang merah plus susu kambing dilakukan melalui 3 tahap, yaitu:

a) Pembuatan susu kacang merah

Kacang merah yang sudah disortir ditimbang sebanyak $500 \mathrm{~g}$ dan direndam 12 jam lalu ditiriskan. Ditambahkan air panas kedalam kacang merah (rasio kacang merah:air=1:3) lalu diblender. Disaring menggunakan kain saring untuk memperoleh susu kacang merah murni. Susu kacang merah dididihkan sambil diaduk, kemudian dimasukkan ke dalam botol dan didinginkan pada suhu kamar25,26. b) Pembuatan yogurt susu kacang merah plus susu kambing

Susu kacang merah yang telah dingin disiapkan ke dalam botol Erlenmeyer untuk ditambahkan dengan susu kambing sesuai dengan proporsi yang telah ditentukan, yaitu P1 (100\% susu kacang merah), P2 (90:10), P3 (80:20), dan P4 (70:30). BAL yang ditambahkan adalah 2 persen. Masing-masing proporsi ditempatkan pada dua tabung yang berbeda untuk membedakan antara produk yang difermentasi selama 12 jam dan 24 jam. Sebanyak 10 persen gula ditambahkn pada masing-masing larutan sebelum dilanjutkan dengan proses pasteurisasi pada suhu $70^{\circ} \mathrm{C}$ selama 20 menit. Ketika proses pasteurisasi berakhir, yogurt didinginkan mencapai suhu $45^{\circ} \mathrm{C}$.

\section{Penentuan Kadar Zat Besi dan Uji Organoleptik}

Kadar zat besi yogurt ditentukan menggunakan metode Spektrofotometri Serapan Atom (SSA). Sedangkan uji organoleptik meliputi uji hedonik dan mutu hedonik. Mutu hedonic meliputi rasa, aroma, kekentalan, warna, dan kesukaan dengan 55 panelis semi terlatih dengan kriteria berusia 1923 tahun, sehat jasmani, bersedia mengikuti penelitian dan mengisi informed consent penelitian, serta berstatus mahasiswa Jurusan Teknologi Pangan, Universitas Jenderal Soedirman. Jenis kelamin panelis relatif seimbang terdiri dari 31 perempuan dan 24 lakilaki.Masing-masing mutu hedonik menggunakan score 1-5. Score rasa adalah: (1) 
tidak asam, (2) agak asam, (3) asam, (4) sangat asam, dan (5) amat sangat asam. Score aroma adalah: (1) tidak khas yogurt, (2) agak khas yogurt, (3) khas yogurt, (4) sangat khas yogurt, dan (5) amat sangat khas yogurt. Score lelentalan adalah: (1) tidak kental, (2) agak kental, (3) kental (4) sangat kental, dan (5) amat sangat kental. Score warna adalah: (1) tidak putih (2) agak putih, (3) putih, (4) sangat putih dan (5) amat sangat putih. Terakhir, score hedonik adalah: (1) tidak suka, (2) agak suka, (3) suka, (4) sangat suka, dan (5) amat sangat suka.

\section{Analisis Statistik}

Kadar zat besi dianalisis menggunakan one-way ANOVA, dilanjutkan dengan uji lanjutan Duncan's Multiple Range Test (DMRT). Hasil uji hedonik dan mutu hedonik dianalisis dengan uji Friedman, dilanjutkan dengan uji banding ganda. Penentuan formula terbaik didasarkan pada kadar zat besi dan mutu hedonik menggunakan indeks efektivitas. Analisis statistik dilakukan dengan menggunakan SPSS versi 24 untuk Windows. Penelitian ini telah mendapat persetujuan
Ethical Clearance dengan nomor 3428/KEPK/VIII/2018

\section{HASIL}

Kadar Fe Yogurt Kacang Merah Plus Susu Kambing

Salah satu mineral yang terkandung dalam yogurt kacang merah plus susu kambing adalah $\mathrm{Fe}$. Kadar total Fe pada produk yogurt di penelitian ini dapat dilihat pada Gambar 1 dan Gambar 2. Hasil sidik ragam menunjukkan bahwa perlakuan lama fermentasi ( $\mathrm{T}$ ) tidak berpengaruh terhadap kadar $\mathrm{Fe}$ yogurt $(P=0,41)$. Hal ini dibuktikan oleh Gambar 1 bahwa tidak terdapat perbedaan kadar Fe yang nyata pada fermentasi 12 jam $(28.75 \mathrm{mg} / \mathrm{L})$ dan 24 jam (27.43 mg/L). Sedangkan pada Gambar 2 berikut menampilkan efek proporsi susu kacang merah:susu kambing terhadap kadar Fe.

Proporsi kacang merah dan susu kambing (P) berpengaruh nyata terhadap kadar $\mathrm{Fe}$ yogurt $(P=0,037)$, kadar tertinggi diperoleh pada perlakuan proporsi kacang merah : susu kambing (90\% : 10\%) yaitu sebesar $32,38 \mathrm{mg} / \mathrm{L}$, dibandingkan P1, P3 dan P4.

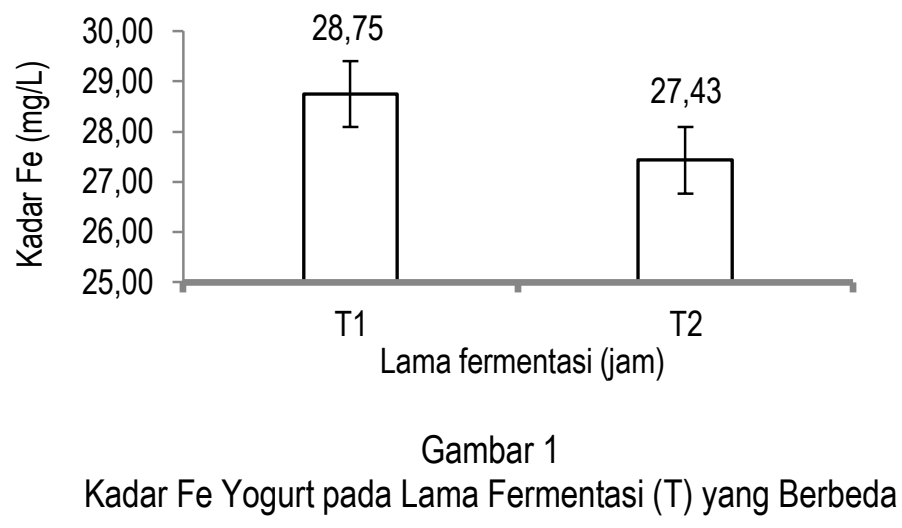

Keterangan: T = Lama Fermentasi; T1 = Lama fermentasi 12 jam; T2 = lama fermentasi 24 jam 


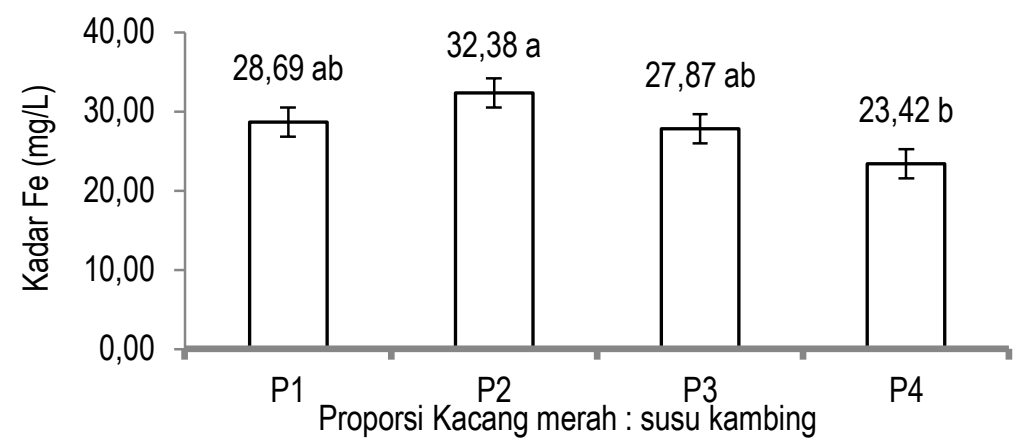

Gambar 2

\section{Kadar Fe Yogurt pada Pada Proporsi Kacang Merah : Susu Kambing $(\mathrm{P})$ yang Berbeda}

Keterangan $: P=$ proporsi kacang merah : susu kambing; $P 1=100: 0$ (kacang merah : susu kambing); $P 2=90: 10$ (kacang merah : susu kambing); P3 = $80: 20$ (kacang merah : susu kambing); P4 = $70: 30$ (kacang merah : susu kambing); Angka yang diikuti huruf yang sama tidak berpengaruh nyata pada alpha 5 persen.

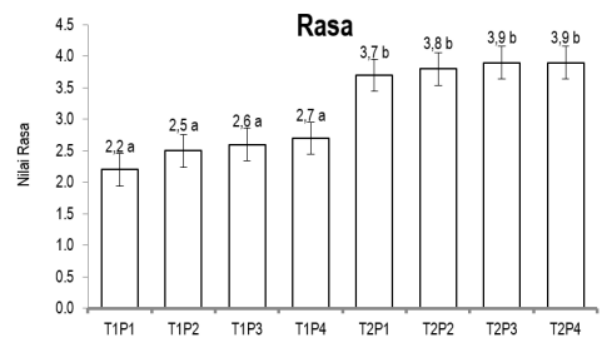

Kombinasi lama fermentasi dan proporsi kacang merah : susu kambing

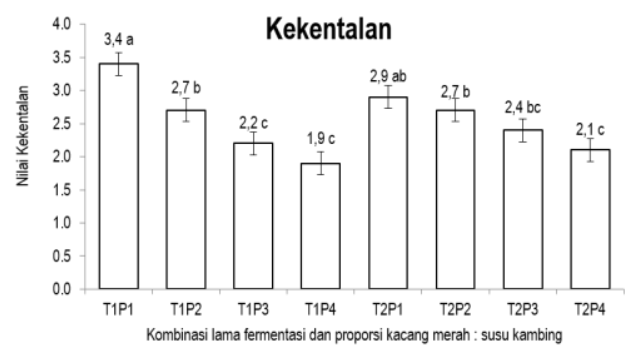

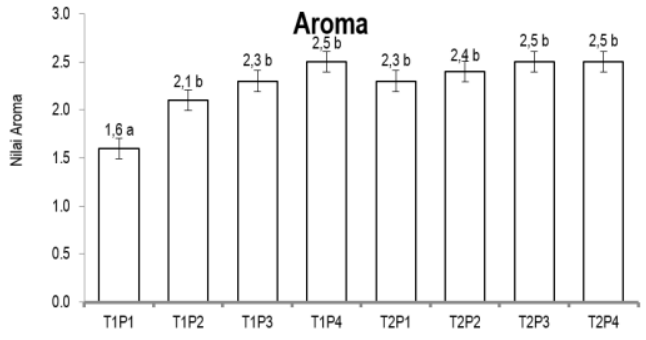

Kombinasi lama fermentasi dan proporsi kacang merah : susu kambing

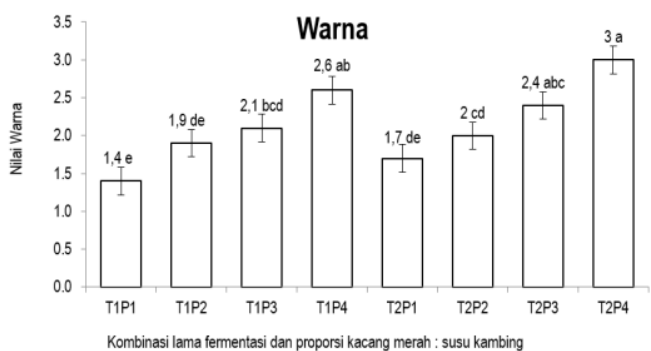

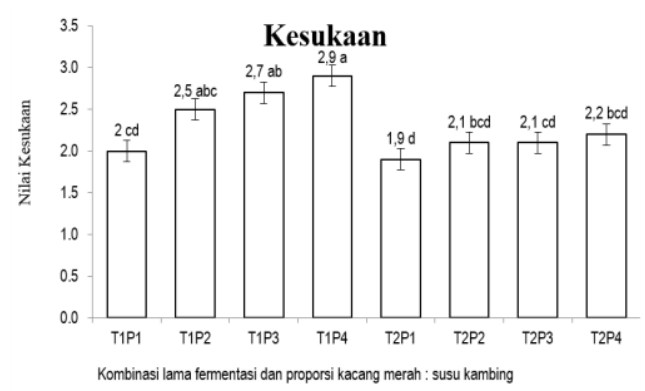

Gambar 3

Nilai Rasa, Aroma, Kekentalan, Warna, dan Kesukaan pada Kombinasi Proporsi Kacang Merah : Susu Kambing dengan Lama Fermentasi

Keterangan:

1) 5 = asam; 4 = agak asam; 3 = sedikit asam; 2 = agak tidak asam; 1 = tidak asam.

2) Angka yang diikuti huruf yang sama tidak berpengaruh nyata pada alpha 5 persen. 


\section{Mutu Hedonik Yogurt}

Hasil analisis terhadap variabel mutu sensori menunjukkan bahwa kombinasi perlakuan lama fermentasi dan proporsi yogurt kacang merah plus susu kambing sangat berpengaruh nyata terhadap rasa, aroma, kekentalan, warna dan kesukaan.

\section{a. Rasa}

Hasil uji Friedman menunjukkan bahwa variasi lama fermentasi dan proporsi yogurt kacang merah plus susu kambing (TP) sangat berpengaruh nyata terhadap rasa yogurt $(P=$ $0,000)$. Berdasarkan Gambar 3 skor tertinggi terhadap rasa yogurt terdapat pada perlakuan T2P3 dan T2P4 sebesar 3,9 yaitu berada dalam kategori antara sedikit asam hingga agak asam, sedangkan skor terendah terdapat pada perlakuan T1P1 sebesar 2,2 yaitu berada dalam kategori agak tidak asam. Nilai rasa yang diharapkan dari yogurt ini adalah rasa asam, sehingga yogurt kacang merah plus susu kambing belum mencapai kadar rasa asam yang diharapkan.

\section{b. Aroma}

Hasil uji Friedman menunjukkan bahwa kombinasi perlakuan antara proporsi dan lama fermentasi yogurt kacang merah plus susu kambing (TP) sangat berpengaruh nyata terhadap aroma yogurt $(P=0,000)$. Nilai aroma yogurt dapat dilihat pada Gambar 3. Berdasarkan Gambar 3 skor tertinggi terhadap penilaian aroma yogurt terdapat pada T1P4, T2P3 dan T2P4 dengan nilai sebesar 2,5 yaitu berkisar antara agak tidak khas hingga sedikit khas yogurt, sedangkan skor terendah terdapat pada T1P1 dengan nilai sebesar 1,6 yaitu berkisar antara tidak khas hingga agak tidak khas yogurt. Aroma yang diharapkan dari produk yogurt kacang merah plus susu kambing yaitu khas yogurt. Seluruh formula yogurt memiliki aroma khas kecuali pada penilaian aroma formula T1P1.

\section{c. Kekentalan}

Hasil uji Friedman menunjukkan bahwa kombinasi perlakuan antara proporsi dan lama fermentasi yogurt kacang merah plus susu kambing (TP) sangat berpengaruh nyata terhadap kekentalan yogurt $(P=0,000)$. Nilai kekentalan yogurt dapat dilihat pada Gambar 3. Berdasarkan Gambar 3 nilai kekentalan yogurt yang didapatkan berkisar 1,9 - 3,4 yaitu dari tidak kental hingga agak kental. Skor kekentalan yogurt tertinggi terdapat pada formula T1P1 dengan nilai sebesar 3,4 yaitu antara sedikit kental hingga agak kental, sedangkan nilai terendah terdapat pada formula T1P4 dengan nilai sebesar 1,9 yaitu berkisar antara tidak kental hingga agak tidak kental. Tekstur yang diharapkan dari yogurt kacang merah plus susu kambing yaitu kental. Yogurt kacang merah plus susu kambing belum mencapai pada kekentalan yang diharapkan.

\section{d. Warna}

Hasil uji Friedman menunjukkan bahwa kombinasi perlakuan antara proporsi dan lama fermentasi yogurt kacang merah plus susu kambing (TP) sangat berpengaruh nyata terhadap warna yogurt $(P=0,000)$. Nilai warna yogurt dapat dilihat pada Gambar 3 . Berdasarkan Gambar 3 nilai warna yogurt yang didapat berkisar antara 1,4-3 yaitu dari tidak putih (keruh) hingga sedikit putih. Skor tertinggi terhadap penilaian warna yogurt kacang merah plus susu kambing terdapat pada T2P4 dengan nilai sebesar 3 yaitu sedikit putih, sedangkan nilai terendah terdapat pada T1P1 dengan nilai sebesar 1,4 yaitu berkisar antara tidak putih atau keruh hingga agak tidak putih.

Warna merupakan salah satu faktor yang sangat bergantung pada penentuan mutu makanan. Warna yang diharapkan dalam yogurt kacang merah plus susu kambing yaitu putih. Yogurt kacang merah plus susu kambing belum mencapai pada warna yang diharapkan.

\section{e. Kesukaan}

Hasil uji Friedman menunjukkan bahwa kombinasi perlakuan antara proporsi dan lama fermentasi yogurt kacang merah plus susu kambing (TP) sangat berpengaruh nyata terhadap kesukaan yogurt $(P=0,000)$. Nilai kesukaan yogurt dapat dilihat pada Gambar 3. Berdasarkan Gambar 3 nilai kesukaan yogurt antara 1,9-2,9 yaitu dari tidak suka hingga sedikit suka. Skor tertinggi terdapat pada formula T1P4 dengan nilai sebesar 2,9 (agak tidak suka hingga sedikit suka), sedangkan nilai terendah terdapat pada T2P1 dengan nilai sebesar 1,9 (tidak suka hingga agak tidak suka). Penilaian kesukaan merupakan penilaian keseluruhan terhadap karakterisktik yogurt 
kacang merah plus susu kambing yang meliputi rasa, aroma, kekentalan dan warna. Yogurt susu kacang merah plus susu kambing yang paling banyak disukai oleh panelis terdapat

\section{BAHASAN}

\section{Kandungan Zat Besi}

Hasil penelitian ini menunjukkan bahwa lama fermentasi tidak berpengaruh nyata terhadap peningkatan kadar Fe yogurt kacang merah plus susu kambing, sejalan dengan temuan penelitian bahwa lama fermentasi tidak berpengaruh nyata terhadap kadar mineral yogurt sinbiotik kacang merah dan kacang hijau $^{27,28}$. Temuan ini tidak sejalan dengan penelitian sebelumnya yang melaporkan adanya peningkatan beberapa kandungan mineral pada soymilk yang difermentasi hingga 54 jam $^{29}$. Peningkatan kandungan mineral selama fermentasi dapat disebabkan karena BAL menghidrolisis ikatan kompleks pada senyawa pengkelat, sehingga mineral $\mathrm{Fe}$ dilepaskan dan meningkatkan ketersediaannya.

BAL juga membutuhkan mineral dan vitamin untuk pertumbuhannya. Dalam penelitian ini, kadar $\mathrm{Fe}$ cenderung menurun seiring dengan bertambahnya waktu fermentasi. Hal ini dimungkinkan karena $\mathrm{Fe}$ digunakan sebagai nutrisi oleh BAL dalam pertumbuhannya. Hal ini sejalan dengan temuan penelitian sebelumnya ${ }^{30}$, bahwa penurunan kadar $\mathrm{Fe}$ disebabkan karena mikroorganisme yang terlibat dalam fermentasi memanfaatkan mineral ini untuk aktifitas fisiologis dan metaboliknya. Hasil penelitian lain mengemukakan, fermentasi kacang jintan Afrika menurunkan beberapa kadar mineral termasuk kadar $\mathrm{Fe}^{31}$. Penurunan kadar tersebut berkaitan dengan peningkatan aktivitas enzim selama fermentasi berlangsung, sehingga kandungan $\mathrm{Fe}$ yang terdapat didalamnya cukup dimanfaatkan oleh enzim.

BAL berfungsi menguraikan senyawasenyawa kompleks dalam susu kacang merah plus susu kambing menjadi lebih sederhana sehingga dapat dengan mudah di cerna oleh usus $^{32}$. Semakin tinggi kadar susu kambing yang ditambahkan maka semakin banyak senyawa-senyawa yang diuraikan oleh BAL, sehingga semakin tinggi energi yang dibutuhkan oleh BAL. Pada pertumbuhannya, BAL turut pada formula T1P3 dan T1P4. Sedangkan produk yang paling sedikit disukai adalah produk T2P4.

menggunakan energi yang berasal dari laktosa ${ }^{33}$. Hal ini dapat membuktikan bahwa semakin tinggi proporsi susu kambing yang ditambahkan, maka semakin banyak energi dan nutrisi yang dibutuhkan oleh BAL guna menguraikan senyawa-senyawa seperti protein, laktosa, dan karbohidrat sehingga menurunkan kadar Fe pada yogurt kacang merah plus susu kambing ini.

Kadar $\mathrm{Fe}$ berasal dari bahan yang digunakan yaitu kacang merah dan susu kambing. Kacang merah mengandung $\mathrm{Fe}$ sebesar $10 \mathrm{mg} / 100 \mathrm{~g}$ bahan ${ }^{34}$, dan susu kambing mengandung $0,05 \mathrm{mg} / 100 \mathrm{ml}$ bahan $^{35}$. Kemungkinan tingginya kadar Fe yogurt berasal dari bahan baku kacang merah, sehingga makin rendah proporsi kacang merah pada yogurt tersebut menurunkan kadar Fe pada hasil akhir produk.

\section{Rasa}

Skor tertinggi rasa yogurt pada penelitian ini adalah sebesar 3.9 dan termasuk kategori sedikit asam hingga agak asam. Hasil ini terdapat pada kelompok T2P3 dan T2P4 dengan perbandingan proporsi kacang merah dan susu kambing 80:20 dan 70:30 dengan waktu fermentasi 24 jam. Penilaian panelis terhadap rasa yogurt meningkat atau semakin asam seiring dengan meningkatnya lama fermentasi dan proporsi susu kambing. Hal tersebut karena BAL semakin banyak memproduksi asam laktat sehingga rasa asamnya semakin meningkat. Penelitian lain menjelaskan bahwa proses fermentasi bakteri Lactobacillus bulgaricus dan Streptococcus thermophillus merombak laktosa menjadi asam laktat ${ }^{36}$. Dengan adanya aktivitas BAL, laktosa yogurt menurun, sedangkan asam laktat meningkat. Dengan terbentuknya asam laktat akan mempengaruhi nilai keasaman pada yogurt.

Penelitian ini sejalan dengan temuan yang meyatakan adanya pengaruh nyata pada proporsi kacang dan susu terhadap rasa yogurt, karena semakin banyak penambahan susu menjadikan rasa semakin asam akibat 
terurainya laktosa susu oleh BAL menjadi asam laktat ${ }^{37}$. Disebutkan pula bahwa semakin banyak penambahan susu membuat rasa yogurt memiliki kualitas rasa semakin baik yaitu rasa asam yang sesuai dengan yang diharapkan.

\section{Aroma}

Skor tertinggi penilaian aroma yogurt pada penelitian ini adalah sebesar 2.5 yang termasuk dalam kategori agak tidak khas hingga sedikit khas yogurt. Penilaian ini terdapat pada kelompok T1P4 dengan proporsi kacang merah dan susu kambing sebesar 70:30 dan 12 jam fermentas, serta kelompok T2P3, dan T2P4 dengan proporsi kacang merah dan susu kambing 80:20 dan 70:30 dengan 24 jam waktu fermentasi. Aroma merupakan indikator yang memberikan hasil penilaian diterima atau tidaknya sebuah produk pangan ${ }^{38}$. Aroma khas minuman fermentasi disebabkan karena asam laktat dan sisa-sisa asetaldehid, diasetil, dan asam asetat yang dihasilkan oleh fermentasi bakteri lactobacillus bulgaricus ${ }^{39}$.

Proporsi kacang merah yang tinggi pada yogurt menyebabkan aroma khas yogurt yang rendah dibandingkan dengan proporsi kacang merah yang lebih sedikit. Hal ini dapat disebabkan bau langu pada kacang merah. Proses fermentasi dapat mengurangi bau langu pada kacang-kacangan karena selama fermentasi susu kacang-kacangan dapat menghasilkan asam-asam organik yang dapat memperbaiki aroma ${ }^{40}$.

Sedangkan penambahan susu kambing dengan proporsi yang lebih besar dapat meningkatkan aroma khas yogurt. Hal ini disebabkan karena susu mengandung tinggi laktosa, sehingga semakin banyak kandungan laktosa, semakin banyak asam laktat yang terbentuk dan berpengaruh pada aroma yogurt ${ }^{41}$. Hal ini membuktikan bahwa aroma yogurt kacang merah plus susu kambing dengan proporsi susu kambing semakin tinggi lebih khas bila dibandingkan yogurt tanpa penambahan susu kambing.

\section{Kekentalan}

Skor tertinggi penilaian tekstur atau kekentalan yogurt pada penelitian ini bernilai 3.4 yaitu sedikit kental hingga agak kental. Hasil ini terdapat pada formula T1P4 yaitu perbandingan proporsi kacang merah dan susu kambing 70:30 dengan 12 jam waktu fermentasi. Tekstur atau kekentalan merupakan aspek mutu makanan karena tekstur mempengaruhi citra makanan baik pada makanan lunak maupun pada makanan renyah ${ }^{38}$. Penilaian panelis terhadap kekentalan yogurt semakin menurun seiring dengan menurunnya proporsi kacang merah dan meningkatnya proporsi susu kambing. Hal ini dapat disebabkan karena semakin banyak susu kambing yang ditambahkan maka semakin tinggi kandungan air yang terdapat dalam yogurt. Penambahan konsentrasi bahan lain dalam pembuatan yogurt memberikan pengaruh terhadap kekentalan yogurt42. Yogurt yang ditambahkan lidah buaya dengan konsentrasi yang lebih tinggi menghasilkan produk yang lebih encer, karena sari lidah buaya meningkatkan kadar air dalam produk yogurt yang dihasilkan.

\section{Warna}

Skor tertinggi penilaian warna pada penelitian ini adalah 3 yaitu sedikit putih dan terdapat pada formula T2P4 yaitu fermentasi selama 24 jam dengan perbandingan kacang merah susu kambing 70:30. Suatu produk yang memiliki kandungan gizi tinggi, enak, dan teksturnya sangat baik, tidak akan dikonsumsi oleh konsumen bila memiliki warna yang tidak enak dipandang ${ }^{38}$. Warna yogurt cenderung semakin putih seiring dengan meningkatnya proporsi susu kambing dan menurunnya kacang merah yang digunakan. Warna putih yang pada yogurt berasal dari susu kambing yang berwarna putih, sehingga warna kacang merah tertutupi oleh proporsi susu kambing yang digunakan dan mempengaruhi warna akhir yogurt. Warna putih yang ditemukan pada yogurt dipengaruhi oleh kandungan kasein pada susu $^{43}$.

\section{Kesukaan}

Skor kesukaan tertinggi penelitian ini sebesar 2.9 yang termasuk agak tidak suka hingga sedikit suka. Nilai ini terdapat pada kelompok T1P4 yaitu 12 jam fermentasi dan proporsi kacang merah susu kambing sebesar 70:30. Uji kesukaan merupakan penilaian terhadap berbagai sifat produk yaitu warna, aroma, rasa dan kekentalan ${ }^{44}$. Kesukaan panelis terhadap yogurt susu kacang merah 
plus susu kambing semakin meningkat seiring bertambahnya proporsi susu kambing. Hal tersebut karena terkait dengan karakteristik sensori yogurt yang semakin lebih baik seiring dengan bertambahnya proporsi susu kambing dan berkurangnya kacang merah, yang ditinjau dari segi rasa, warna, kekentalan dan aroma. Perbedaan rasa suka ataupun tidak suka oleh panelis bergantung pada kesukaan panelis terhadap masing-masing perlakuan dengan berbagai proporsi. Meskipun demikian, kesukaan panelis terhadap suatu produk bersifat relatif sehingga tidak serta-merta menentukan formulasi produk yogurt terbaik.

\section{Perlakuan Terbaik}

Perlakuan terbaik produk diperoleh menggunakan metode uji indeks efektivitas untuk mendapatkan formula terbaik yogurt kacang merah plus susu kambing ditinjau dari kadar $\mathrm{Fe}$ dan kualitas sensori berdasarkan berbagai variasi perlakuan proporsi dan waktu fermentasi.

Berdasarkan uji efektivitas didapat hasil perlakuan terbaik yaitu formula yogurt kacang merah plus susu kambing T2P2 dengan proporsi kacang merah : susu kambing sebesar 90 persen : 10 persen dan lama fermentasi 24 jam. Yogurt dengan formula T2P2 memiliki kandungan $\mathrm{Fe}$ sebesar 33,62 $\mathrm{mg} / \mathrm{L}$. Berdasarkan hasil uji kualitas sensori, yogurt kacang merah plus susu kambing formula T2P2 memiliki rasa asam hingga sangat asam, beraroma agak khas yogurt hingga khas yogurt, bertekstur agak kental hingga kental, berwarna agak putih dan secara keseluruhan agak disukai oleh panelis.

Formula terpilih yogurt kacang merah susu kambing dibandingkan dengan syarat mutu yogurt SNI 2981:2009 agar dapat diketahui mutu produk dengan syarat mutu yogurt yang sudah ditetapkan. Pada penelitian ini, formula T2P2 telah memenuhi sebagian Standar Nasional Indonesia (SNI) 2981:2009 mengenai syarat mutu yogurt45. Syarat mutu yang terpenuhi adalah tekstur yaitu sedikit kental serta syarat yang belum terpenuhi yaitu rasa (agak asam) dan aroma (sedikit khas).

\section{Per Serving Size Yogurt}

Penentuan serving size yogurt dilakukan untuk mengetahui banyaknya yogurt yang dikonsumsi untuk memenuhi kebutuhan asupan
Fe harian remaja putri usia 15 - 25 tahun berdasarkan AKG 2013. Serving size produk ditetapkan pada formula terbaik yaitu produk T2P2 dengan kandungan Fe sebesar 33,62 $\mathrm{mg} / \mathrm{L}$. Jumlah pemenuhan kebutuhan tersebut harus disesuaikan dengan standar syarat makanan selingan yaitu pemenuhan 10 persen dari total kebutuhan $\mathrm{Fe}^{46}$.

Bagi remaja putri normal, aturan serving size yang ditetapkan adalah $80 \mathrm{ml}$ dengan persentase pemenuhan kebutuhan $\mathrm{Fe} 10.35$ persen. Sedangkan bagi remaja putri anemia, aturan serving size yang ditetapkan adalah 100 $\mathrm{ml}$ dengan presentase pemenuhan kebutuhan 10.64 persen. Temuan produk ini tidak akan bersaing dengan program gizi pemerintah terkait pemberian Tablet Tambah Darah (TTD) untuk pemenuhan kebutuhan Fe remaja putri. Lebih jauh, yogurt kacang merah plus susu kambing ini dapat mendukung program pemerintah untuk mengatasi anemia defisiensi besi karena dapat memenuhi kebutuhan $\mathrm{Fe}$ remaja putri dan dapat menjadi alternatif pilihan minuman untuk remaja putri anemia.

\section{SIMPULAN DAN SARAN}

\section{Simpulan}

Formula terbaik untuk yogurt kacang merah plus susu kambing berdasarkan temuan pada penelitian ini adalah produk yang mengalami waktu fermentasi 24 jam, dengan proporsi kacang merah 90 persen dan susu kambing 10 persen. Sebanyak $80 \mathrm{ml}$ yogurt kacang merah plus susu kambing formula terbaik ini mengandung $2.69 \mathrm{mg} / \mathrm{ml}$ zat besi, sehingga dapat dijadikan sebagai snack sehat untuk memenuhi kebutuhan zat besi harian bagi remaja anemia.

\section{Saran}

Studi lebih lanjut terkait produk ini perlu dilakukan untuk melihat kandungan gizi lain seperti protein, lemak, karbohidrat maupun aktivitas antioksidan yang mungkin terkandung di dalamnya. Selain itu, pemberian yogurt kacang merah plus susu kambing kepada remaja putri anemia perlu dilakukan untuk melihat efeknya terhadap perbaikan status anemia. 


\section{UCAPAN TERIMA KASIH}

Penulis ingin mengucapkan terima kasih yang mendalam kepada Lembaga Penelitian dan Pengabdian Masyarakat, Universitas Jenderal Soedirman yang telah membiayai penelitian ini.

\section{RUJUKAN}

1. Ahluwalia N, Dalmasso $P$, Rasmussen M, Lipsky L, Currie C, Haug E, et al. Trends in overweight prevalence among 11-, 13-and 15-year-olds in 25 countries in Europe, Canada and USA from 2002 to 2010. Eur J Public Health. 2015;25(suppl_2):28-32.

2. Cleobury L, Tapper K. Reasons for eating 'unhealthy'snacks in overweight and obese males and females. J Hum Nutr Diet. 2014;27(4):333-41.

3. Flegal KM, Kruszon-Moran D, Carroll $M D$, Fryar $C D$, Ogden CL. Trends in obesity among adults in the United States, 2005 to 2014. Jama. 2016;315(21):2284-91.

4. Manyanga T, El-Sayed H, Doku DT, Randall JR. The prevalence of underweight, overweight, obesity and associated risk factors among schoolgoing adolescents in seven African countries. BMC Public Health. 2014;14(1):887.

5. Marriott BP, White A, Hadden L, Davies JC, Wallingford JC. World Health Organization (WHO) infant and young child feeding indicators: associations with growth measures in 14 low-income countries. Matern Child Nutr. 2012;8(3):354-70.

6. Yoon J-S, Lee N-J. Dietary patterns of obese high school girls: snack consumption and energy intake. Nutr Res Pract. 2010;4(5):433-7.

7. Al-Rethaiaa AS, Fahmy A-EA, AlShwaiyat NM. Obesity and eating habits among college students in Saudi Arabia: a cross sectional study. Nutr J. 2010;9(1):39.

8. Chang Y-J, Lin W, Wong Y. Survey on Eating Disorder-Related Thoughts, Behaviors, and Their Relationship with
Food Intake and Nutritional Status in Female High School Students in Taiwan. J Am Coll Nutr. 2011;30(1):3948.

9. Neslişah R, Emine AY. Energy and nutrient intake and food patterns among Turkish university students. Nutr Res Pract. 2011;5(2):117-23.

10. Washi SA, Ageib MB. Poor diet quality and food habits are related to impaired nutritional status in 13-to 18-year-old adolescents in Jeddah. Nutr Res. 2010;30(8):527-34.

11. Andiarna F. Analysis of Breakfast Habits on The Incidence of Anemia. In: International Conference on Sustainable Health Promotion. 2018. p. 25-9.

12. Brown JE. Nutrition through the life cycle. Cengage Learning; 2016.

13. Starn AL, Udall Jr JN. Iron deficiency anemia, pica, and restless legs syndrome in a teenage girl. Clin Pediatr (Phila). 2008;47(1):83-5.

14. Al Hassan NN. The prevalence of iron deficiency anemia in a Saudi University female students. J Microsc Ultrastruct. 2015;3(1):25-8.

15. Kassebaum $\mathrm{NJ}$, Jasrasaria $\mathrm{R}$, Naghavi M, Wulf SK, Johns N, Lozano R, et al. A systematic analysis of global anemia burden from 1990 to 2010. Blood. 2014;123(5):615-24.

16. Benoist B de, McLean E, Egll I, Cogswell M. Worldwide prevalence of anaemia 1993-2005: WHO global database on anaemia. Worldw Preval anaemia 1993-2005 WHO Glob database anaemia. 2008;

17. Dardjito E, Anandari D. Anemia gizi besi pada remaja putri di wilayah kabupaten banyumas. Kesmas Indones. 2016;8(01):16-31.

18. McClean PE, Lee RK, Miklas PN. Sequence diversity analysis of dihydroflavonol 4-reductase intron 1 in common bean. Genome. 2004;47(2):266-80.

19. Zielińska-Dawidziak M, Hertig I, Staniek $\mathrm{H}$, Piasecka-Kwiatkowska D, Nowak $\mathrm{KW}$. Effect of iron status in rats on the absorption of metal ions from plant ferritin. Plant foods Hum Nutr. 2014;69(2):101-7. 
20. Yudhistiwa A, Puspita D. Yoghurt "HCPT"(High Calorie and Protein for Tuberculosis Disease) dengan formulasi sinbiotik kacang merah dan susu kambing dalam daya hambat myobacterium tuberculosis. 2014;

21. Orviyanti G, Murwani R. Perbedaan Pengaruh Yoghurt Susu, Jus Kacang Merah dan Yoghurt Kacang Merah terhadap Kadar Kolesterol LDL dan Kolesterol HDL Serum pada Tikus Dislipidemia. Fakultas Kedokteran; 2012.

22. Vargas $M$, Cháfer $M$, Albors $A$, Chiralt A, González-Martínez C. Physicochemical and sensory characteristics of yoghurt produced from mixtures of cows' and goats' milk. Int Dairy J. 2008;18(12):1146-52.

23. Domagała J. Instrumental texture, syneresis and microstructure of yoghurts prepared from goat, cow and sheep milk. Int $\mathrm{J}$ Food Prop. 2009;12(3):605-15.

24. Omaea M, Maeyama $Y$, Nishimura T. Sensory properties and taste compounds of fermented milk produced by Lactococcus lactis and Streptococcus thermophilus. Food Sci Technol Res. 2008;14(2):183-9.

25. Srianta I, Trisnawati CY. Pengantar Teknologi Pengolahan Minuman. Pustaka Pelajar; 2015.

26. Kumalaningsih $\mathrm{S}$, Pulungan $\mathrm{MH}$, Raisyah R. Substitusi Sari Kacang Merah dengan Susu Sapi dalam Pembuatan Yogurt. Ind J Teknol dan Manaj Agroindustri; Vol 5, No 2 (2016)DO

1021776/ub.industria2016005021

[Internet]. 2016 Aug 15; Available from: http://industria.ub.ac.id/index.php/indust ri/article/view/270

27. Yasinta P. Mempelajari Pengaruh Lama Fermentasi terhadap Pengembangan Pangan Fungsional Yogurt Sinbiotik Kacang Merah dan Kacang Hijau. Skripsi Bogor Fak Ekol Manusia Inst Pertan Bogor. 2015;

28. Yuniati H. Kemampuan Fermentasi Bakteri Lactobacillus Bulgaricus Untuk Menghasilkan Susu Rendah Laktosa Dari Susu Yang Rusak. Indones Bull
Heal Res. 2012;40(1).

29. Obadina AO, Akinola OJ, Shittu TA, Bakare HA. Effect of natural fermentation on the chemical and nutritional composition of fermented soymilk nono. Niger food J. 2013;31(2):91-7.

30. Afoakwa EO, Kongor JE, Takrama JF, Budu AS. Changes in acidification, sugars and mineral composition of cocoa pulp during fermentation of pulp pre-conditioned cocoa (Theobroma cacao) beans. 2013;

31. Chikwendu JN, Obiakor-Okeke PN, Nwabugo MA. Effect of Fermentation on the Nutrient and Antinutrient Composition of African Yam Bean (Sphenostylisstenocarpa) Seeds And Pearl Millet (Pennisetumglaucum) Grains. Int J Sci Technoledge. 2014;2(12):169.

32. Fardiaz DS. Mikrobiologi pangan 1. PT Gramedia; 1992.

33. Rossi E, Hamzah F, Febriyani $F$. Perbandingan Susu Kambing dan Susu Kedelai dalam Pembuatan Kefir. J Peternak Indones. 2016;18(1):13-20.

34. USDA. Beans, Kidney, California red, Mature Seeds, Raw. 2007.

35. USDA. Basic Report: 01106. 2017.

36. Kusumaningrum AP. Kajian total bakteri probiotik dan aktivitas antioksidan yoghurt tempe dengan variasi substrat. Universitas Sebelas Maret; 2011.

37. Widiastuti A, Judiono J. Pengaruh substitusi sari kacang komak (lablab purpureus (l.) Sweet) dan susu skim terhadap sifat organoleptik, nilai ph, dan total bakteri asam laktat yoghurt kacang komak. Media Gizi Indones. 2018;12(1):72-9.

38. Agusman. Pengujian Organoleptik [Internet]. Semarang; 2013 [cited 2018 Nov 6]. Available from: http://tekpan.unimus.ac.id/wpcontent/uploads/2014/03/UjiOrganoleptik-Produk-Pangan.pdf

39. Winarno FG, Fernandez IE. Susu dan Produk Fermentasinya. M-brio Press Bogor. 2007;

40. Yusmarini ER, Efendi R. Evaluasi mutu soygurt yang dibuat dengan penambahan beberapa jenis gula. $\mathrm{J}$ 
Natur Indones. 2004;6(2):104-10.

41. Fitriani NH. Uji kualitas organoleptik yoghurt berbahan baku susu biji cempedak (Artocarpus Champenden) berdasarkan lama waktu fermentasi. IAIN Palangka Raya; 2015.

42. Aminah S. Karakteristik Fisik, Kimia, Dan Sifat Organoleptik Yoghurt Dengan Campuran Berbagai Konsentrasi Sari Lidah Buaya (Aloe Vera). J Pangan dan Gizi. 2012;3(1).

43. Khoiriyah LK, Fatchiyah F. Karakter Biokimia dan Profil Protein Yogurt Kambing PE Difermentasi Bakteri Asam Laktat (BAL). J Exp Life Sci. 2013;3(1):1-6.
44. Triyono A. Mempelajari pengaruh maltodekstrin dan susu skim terhadap karakteristik yoghurt kacang hijau (Phaseolus radiatus L.). 2010;

45. Indonesia SN. SNI 2981: 2009. Yogurt Badan Stand Nas (BSN), Jakarta. 2009;

46. Indonesia KKR. Pedoman praktis memantau status gizi orang dewasa. Jakarta: Departemen Kesehatan Republik Indonesia; 2003. 